\title{
ОБУЧЕНИЕ ЭСТРАДНО-ДЖАЗОВОМУ ВОКАЛУ В ЮНОШЕСКОМ ВОЗРАСТЕ: ТЕХНОЛОГИИ И МЕТОДИКИ РАБОТЫ
}

\author{
Золотухина Анна-Мария Сергеевна \\ студент \\ Научный руководитель: Каминская Елена Альбертовна \\ к.П.н., профессор \\ АНО ВО «Институт современного искусства»
}

\begin{abstract}
Аннотация: В статье рассматриваются основные принципы работы в обучении эстрадно-джазового вокала с учениками юношеского возраста: психофизиологические особенности данного периода. Определяются педагогические принципы и условия, способствующие эффективности работы в данном направлении; изучаются технологии и методики вокального искусства.

Ключевые слова: Эстрадно-джазовое пение; юношеский возраст; методики вокала; музыкально-творческая деятельность; психофизиологические особенности.
\end{abstract}

\section{TEACHING POP AND JAZZ VOCALS IN ADOLESCENCE: TECHNOLOGIES AND METHODS OF WORK}

\section{Zolotukhina Anna-Maria Sergeevna Kaminskaya Elena Albertovna}

\begin{abstract}
The article discusses the basic principles of working with young students: psychophysiological features of this period. It describes the technologies and methods of training, as well as practical recommendations for training; the technologies and methods of vocal art are studied.
\end{abstract}

Key words: Pop-jazz singing; youth age; vocal techniques; musical and creative activity; psychophysiological features.

Не стоит сомневаться, что искусство обладает особым воздействием на человека. Оно направляет, развивает, углубляет эмоции, заставляет работать мысль, расширяет кругозор, оказывает влияние на духовный мир и становление 
человека в целом. Одним из видов сценического искусства является эстрада. Она отличается многообразием форм существования и жанровой структуры. Концерты эстрадно-джазовых певцов привлекают к себе внимание многомиллионной аудитории. Популярность эстрадных конкурсов в настоящее время свидетельствуют об огромном желании современной молодежи заниматься сольным вокальным исполнительством. Выступающие солисты демонстрируют свое мастерство, несмотря на молодые годы. Несомненно, это заслуга педагогов. Неоднократно проблема подготовки начинающего вокалиста освещалась в научно-педагогической литературе. Вопросами профессионализма в музыке занимались еще со времен античности [1, с. 87]. Изучая современные труды вокальной педагогики, выделяются работы следующих авторов: А.С. Поляков, И.Б. Бархатова, Е.Ю. Белоброва, А.Е. Варламов, О.В. Васильева, Л.Б. Дмитриев, И.А. Никулина, С. Риггс и другие.

Данные работы рассматривают вопросы, занимающиеся формированием голосового аппарата, развитием техники, постановки дыхания, сценического опыта. На педагогов по вокалу ложится огромная ответственность за воспитание молодежи, поэтому руководитель должен быть не только профессионалом, но и обладать знаниями в области физиологии и психологии юношеского возраста.

Основной идеей статьи являются психофизиологические особенности юношеского возраста: работа с голосовым аппаратом в данный период. «Физиология и психофизиология ребенка - необходимый компонент знаний любого специалиста, работающего с детьми» [2, с. 3]. Главная теоретическая задача физиологии развития - выявление основных закономерностей возраста. С помощью этой науки, мы знаем, как растет и развивается организм в разном возрасте, понимаем особенности физиологического, личностного, социального развития.

Изучая мнения психологов, можно сделать вывод: в ранней юности школьники находятся на абсолютно разных стадиях развития, эмоционально психологического фона.

Поздняя юность -18 - 22 года - особенно важное время в становлении личности. Это явный переход от детства к самостоятельности и ответственности взрослой жизни. Безусловно, юношеский возраст проходит у каждого по-разному. Стоит отметить такое понятие, как юношеский максимализм. Максимализм - этакое впадение в крайность в момент 
требования чего-либо. Неумение понимать и слышать, жесткость и принципиальность - черты, которые свойственны переходному возрасту и юношескому. Если в подростковом возрасте это объясняется физиологией и измененным гормональным фоном, то в юношестве - это поиск собственного «Я».

Также в работе нам необходимо рассмотреть физиологические особенности юношеского возраста, связанные с вокальным аппаратом.

Дыхание, его частота и глубина - две основные характеристики, из которых состоит дыхательный акт. Число дыхательных актов в минуту, называется частотой. Во взрослом возрасте эта величина около 12-15, в то время как у младенцев 50-60 в минуту. Противоположный принцип имеет глубина дыхания. У новорожденных дыхательный объем мал: около 30 мл., в то время как у взрослого 500 мл. Это объясняется, что взрослый человек может долгое время задерживать дыхание, исполнять длительные фразы на одном дыхании.

Легкие - орган дыхания человека. Поверхность легких состоит из слизистой оболочки. Сама поверхность в 50 раз больше поверхности всего кожного покрова человека. Трахея напоминает трубку примерно 12 см длиной. Ведущая вдыхательная мышца - диафрагма, расположенная горизонтально; является грудобрюшной перегородкой.

Цикл дыхания состоит из трех фаз: вдох, выдох и пауза. Вдох и выдох по продолжительности примерно равны, но при фонации фаза выхода намного длиннее вдоха. При пении вдох совершается быстрее, но медленнее при разговоре. В свою очередь, выдох осуществляется за счет сокращений мышц брюшного пресса. Возможности сокращений этих мышц создают основу для выработки певческого дыхания, соответствуя требованиям вокальной фразы и содержанием музыкального текста. Существуют 3 типа дыхания: реберное, брюшное и смешанное. Реберное дыхание, в свою очередь, бывает трех разновидностей: ключичное, верхнереберное и нижнереберное. Нижнереберное считается наиболее рациональным, так как количество вдыхаемого воздуха оказывается намного больше, чем при ключичном или верхнереберном [3, с. 17].

Гортань - орган, который тесно связан с дыхательной функцией, место, где зарождается звук. Строение гортани: хрящевой скелет и связочный аппарат. В период юношества гортань полностью сформирована и находится на уровне IV-VII шейных позвонков. 
Хрящевой скелет состоит из трех непарных хрящей: перстневидный, щитовидный и надгортанный, а также трех парных: пирамидальные верхушки, клиновидные вокальные отростки и черпаловидные. Объединяясь, они образуют цилиндрическую форму, характерную для потока воздуха.

Голосовые складки - складка слизистой оболочки гортани, которая содержит голосовую связку и мышцу. Принято считать, что полностью сформированный голосовой аппарат в возрасте 17-18 лет, когда прошел период мутации голоса. Тем самым, навредить своего голосу в юношеском возрасте, вероятность намного ниже, нежели в детском, либо в подростковом.

Безусловно, забота и гигиена голоса играют огромную роль в жизни будущего исполнителя, а также правильная методика обучения и регулярные посещения фониатра.

Физическое развитие считается завершенным к началу юношеского возраста, но некоторые данные свидетельствуют, что это не так. Даже в юношеском возрасте продолжаются изменения частей тела (длины, ширины плеч и тела), это связано с изменением гормонального фона. Если внешне человек полностью сформирован, гормональные перестройки, связанные с половым созреванием, все еще продолжаются. В юношеском возрасте начинают взаимодействовать отдельные звенья эндокринной системы, которые в свою очередь обеспечивают совершенствование процессов.

Таким образом, мы определили физиологические и психологические особенности юношества: данный возрастной период наиболее восприимчив к профессиональным занятиям по вокалу. Практически полные, сформированные голосообразующие органы и голосовой аппарат, в целом. Гортань, легкие (которые достигли размера взрослого человека), голосовые связки(складки), прилегающие к ним хрящи. Психологические особенности: развита память, которая позволяет запомнить методы изложения информации, вокальные тренировки, а также научиться проецировать изложенную информацию педагогом на свой организм, с помощью внимания и мышления.

В сложном и динамичном образовательном процессе педагогу приходится решать бесчисленное множество типовых и оригинальных педагогических задач, которые всегда являются задачами социального управления, поскольку обращены к всестороннему развитию личности. Как правило, задачи эти со многими неизвестными, со сложным и вариативным составом исходных данных и возможных решений. Чтобы уверенно прогнозировать искомый результат, принимать безошибочные научно 
обоснованные решения, педагог должен профессионально владеть методами педагогической деятельности.

Методы осуществления педагогического процесса и методические приемы тесно связаны между собой, могут совершать взаимопереходы, заменять друг друга в конкретных педагогических ситуациях. В одних обстоятельствах метод выступает как самостоятельный путь решения педагогической задачи, в других - как прием, имеющий частное назначение.

Хотелось бы обратить внимание на то, что практически каждый урок эстрадно-джазового вокала, за исключением выступлений, строится по следующему принципу:

- артикулячионная разминка, разогрев

- дыхательная гимнастика

- распевание, вокальные упражнения

- информативная часть занятия

- работа над репертуаром

- репетиционная практика

Хотя, безусловно, педагог всегда должен оставлять пространство для импровизации в построении своего занятия, часто гораздо более эффективно принять во внимание физическое и эмоциональное состояние учеников, нежели слепо следовать плану.

Знакомство учеников с голосовым аппаратом начинается с понимания того, как он устроен. На этом этапе очень важно объяснить, что такое диафрагма, гортань, голосовые связки, мышцы брюшного пресса, носоглотка, где они находятся и как взаимодействуют между собой, а также каким образом происходит процесс дыхания и какие виды дыхания существуют (грудной, брюшной и смешанный). Несомненно, основой для каждого педагогавокалиста, является труд Л.Б.Дмитриева. В своей книге «Основы вокальной методики» освещаются теоретические обоснования постановки голоса и голосообразования, а также практические [4, с. 675].

Дыхательные упражнения, такие как: воздушный шарик, собачка, насос, змейка, поезд, - помогут ученику понять, как правильно дышать.

Далее следует расшифровать ученикам такие понятия, как тембр, регистр (грудной, головной, смешанный), диапазон [5, с. 352]. Необходимо также дать им информацию о типах певческих голосов (мужские - тенор, баритон, бас; женские - сопрано, меццо-сопрано, альт; и детские) и разновидностях вокальных ансамблей (мужские, женские, детские, смешанные). 
Затем необходимо рассмотреть такое понятие, как атака звука (мягкая, твердая, придыхательная). Все это необходимо, чтобы на последующих этапах разговаривать с учениками на одном языке. И, конечно, важно расшифровать понятие динамики в вокальном искусстве (понятия форте, пиано, меццо-форте, меццо-пиано). Для этой цели хорошо подходит упражнения: мяч, секрет, котик, свеча и другие.

Таким образом, мы убедились, что юношество - подходящий период для профессионального обучения пению. Рассмотренные методики и технологии позволяют раскрыть певческий голос ученика юношеского возраста. Используя теоретические знания, а также практические умения и навыки, ученик сможет исполнять вокальный материал различной стилистики. Сможет петь ровным, свободным звуком, используя все многообразие красок своего природного тембра, уверенно держаться на сцене, создавать сценический образ, а также владеть различными вокальными штрихами и приемами. Распевки и упражнения должны подбираться педагогом, соответствуя с уровнем подготовки учащегося. Именно движением от простого к сложному осуществляется принцип постепенности. Упражнения могут подбираться как комплексом на несколько существующих пробелов, так и изолированно. Но педагог должен помнить: без закрепления пройденного материала, двигаться дальше нельзя.

\section{Список литературы}

1. Лосев, А.Ф. Античная музыкальная эстетика // Вступительный очерк и собрание текстов. - Москва: Музгиз, - 1960. - 304 с.

2. Безруких, М.М. Возрастная физиология. - Москва: Академия, - 2003. $-414 \mathrm{c}$.

3. Вербов, А.М. Техника постановки голоса. Москва: Мургиз, 1961. 52 с.

4. Дмитриев, Л.Б Основы вокальной методики. - Москва: Издательство Музыка, - 2007. - 675 с.

5. Александрова, Н.А. Вокал. Краткий словарь терминов и понятий. Москва: - 2015. - 352 с. 